\title{
Community Experiences in the use of Modified Taungya System for Restoring Degraded Forests and Improving Livelihoods in Ghana
}

\author{
Mark Appiah (Corresponding author) \\ CSIR - College of Science and Technology, Cantonments, Accra, Ghana \\ CSIR - Forestry Research Institute of Ghana, P.O. Box UP 63, Kumasi, Ghana \\ University of Eastern Finland, School of Forest Sciences, PL 111, 80101 Joensuu, Finland \\ Tel: 233-503-632-061Ｅ-mail: anmark.appiah@gmail.com \\ Badu Yeboah \\ University of Energy and Natural Resources, Post Office Box 214, Sunyani, Ghana
}

Mary Agyemang Yeboah

CSIR - College of Science and Technology, Cantonments, Accra, Ghana

Jones Abrefa Danquah

Department of Geography and Regional Planning, Faculty of Social Sciences

College of Humanities and Legal Studies, University of Cape Coast, Ghana

Received: April 14, 2020 Accepted: May 7, 2020 Published: May 17, 2020

doi:10.5296/emsd.v9i3.17047～URL: https://doi.org/10.5296/emsd.v9i3.17047

\begin{abstract}
Using the Modified Taungya System (MTS) to establish plantations has been identified as one of the important strategies required to meet the demand for wood resources in Ghana. The MTS is a forest management approach in which farmers are given lands within degraded forest reserves to inter-plant food crops with trees, and further nurture the trees into maturity under specified roles and benefit sharing agreements. This study evaluated the MTSs and
\end{abstract}


management approach based on the following sustainability criteria: recognition of gender role in agroforestry development, contribution of the systems to poverty reduction, and contribution of the systems to the improvement in productive and protective functions of agriculture. The systems were established in degraded portions of the Pamu-Berekum Forest Reserve, Ghana in 2000. Data were collected in 2016 through personal interviews of 40 farmers selected from three communities living close and around the forest reserve. It is clear from the result that women participation in the project activities is significant and may have contributed to the reported successful outcome. More than a decade after the establishment of these plantations, there is evidence that the non-timber forest products, (e.g. fuelwood, medicine) generated from practising MTS have had a significant impact on the community livelihood with significant changes in annual income. Also, the farms clearly have many trees surviving that have economic, social, and ecological significance. The MTS, indeed, has the potential to support biodiversity recovery within degraded forest reserves in Ghana as well as to improve the livelihoods of farmers.

Keywords: Modified taungya, Women in agriculture, Forest rehabilitation, Poverty reduction

\section{Introduction}

The Ghanaian forests are essential to the livelihoods for many people in Ghana (Appiah et al., 2007; Danquah et al., 2012; Appiah, 2013). Apart from providing timber, forests offer other important ecosystem services, such as erosion protection, biodiversity protection, clean water, wildlife, and recreation. Also, forests offer other services that serve as source of employment, cultural and aesthetic uses, and subsistence uses, as well as serving as sources of direct or indirect income (Blay et al., 2007; Bauhus et al. 2010; Appiah 2013). However, Ghana's forests are being lost at an increasing pace (Danquah et al., 2012). The alarming loss of forest habitat is leading to the loss of timber and biodiversity. This is happening while at the same time there are growing demands for forest products for the local, national and global markets (Jonsson, 2009). Furthermore, the issue of climate change has put additional demands on the forest in terms of both providing biomass and serving as a carbon sink (Pugh et al., 2019; Remeš et al., 2020). Thus, there is a need to respond to the growing interest in forest products and to address biodiversity loss, but to do so in a sustainable way. The main causes of forest loss and degradation in Ghana include the clearing of forest for cultivation of cocoa and farming of other crops; the harvesting of fuel wood; mining; forest fires; infrastructure development; and both legal and illegal logging (Appiah et al., 2010). Behind these main causes, there are also other factors such as low institutional capacity for environmental management, low awareness about the effects of human activities on the environment, and limited human and financial resources to implement reforestation and other management programmes.

Human intervention is required to facilitate the rehabilitation of degraded forest lands to restore the capacity of degraded forest lands to deliver forest products and services (Blakesley et al., 2002; Appiah, 2013). Restoring and rehabilitating the forest can be done through protective measures (e.g. protection from fire or grazing and erosion control), and through measures to accelerate natural recovery (e.g. through planting of seedlings or direct 
seeding in degraded forests). Restoration and rehabilitation of degraded forests can be done also through assisted natural regeneration (e.g. thus, weed control on degraded forest lands), and by planting native or exotic trees in single-species or mixed-species stands (Danquah, 2012). Most of the rehabilitation interventions in the tropics have involved the establishment of plantations, usually fast-growing exotic species including tropical pines, Eucalyptus species, Tectona grandis, Gmelina arborea and some Acacia species (Carpenter et al., 2004) to provide important economic, social, and environmental services (Mansourian, 2005). Until recent years, the retention of indigenous forest trees within plantation forests to provide habitat for many indigenous species has been rarely practiced (Rad Eshaghi et al., 2009). Some researchers have used indigenous or local tree species as plantation species to test recruitment within these plantations. The results showed that the local species used could foster species regeneration (Montagnini, 2000; Blakesley et al., 2002).

In Ghana, the MTS has been one of the options for forest rehabilitation involving the retention and planting of indigenous trees species for rehabilitation and restoration of degraded forest lands. Taungya, which means hill (Taung) cultivation system, is reported to have started in Myanmar (Burma) (Blanford, 1958). The taungya system is defined as a method of establishing a forest crop in temporary association with agricultural crops (Blanford, 1958). It is a method of raising forest plantations in which cultivators can raise agricultural crops for initial periods of a few years and in return they are required to raise forest plantations. Thus, it is a form of agroforestry system in which short rotation crops are grown during the early years of tree plantation establishment. This approach allows cultivators to utilize the land, control weeds, reduce plantation establishment costs, generate early income, and stimulate the development of the woody perennial species (UPSTree, 2017). This is a modified form of shifting cultivation in which labour is permitted to raise crops in an area but only side by side with the forest species planted by them. The practices consist of land preparation, tree planting, growing an agricultural crop for 1 to 3 years until shade becomes too dense and then moving on to repeat the cycle in a different area. The Taungya systems practiced traditionally consist of planting trees on prepared lands, growing agricultural crops for one to three years when the tree cover overshadows the crops and moving on to another degraded area to repeat the cycle. (Agyeman et al., 2003a).

The taungya system has been practiced in Ghana with modification since 2002 (termed as Modified Taungya System (MTS) with the aim to support both rural livelihoods and Ghana's deforestation problem. The MTS is an improved version of the old taungya system that was suspended in 1984 due to the limited co-operation its implementation received from farmers. Under the practices of the old taungya system, farmers did not get economic benefits from the trees. But now, under the MTS, farmers are given portions of degraded forest reserves lands to plant trees and inter-plant them with food crops, and further nurture trees into maturity under an agreement in which roles and benefit sharing are specified (Agyeman et al., 2003a). In this arrangement, both the Forestry Commission, Ghana and selected forest fringe communities have roles and also future benefits from the planted trees. Under the MTS, farmers gain access to land offered by the Forestry Commission, Ghana to grow food crops together with the planted forest trees. The legally binding arrangement amongst the major 
stakeholders stipulates that, when the timber is sold, the benefits must be shared between the Forestry Commission (40\%), the farmers (40\%), the traditional landowners $(15 \%)$ and the forest-adjacent community (5\%) (Yeboah, 2016). The farmers are entitled to $100 \%$ of the benefits from the food crops cultivated (Danquah, 2015; Agyeman et al., 2003b). This added benefit sharing scheme recognizes the fact that incentives can increase the participation of forest-based communities and local structures in forest resource management (Ribot and Larson, 2005; Ribot and Oyono, 2006).

Unfortunately, most rehabilitation and restoration programmes have been largely exploitative and unattractive to local people who are key land users. Consequently, most national and international development programmes have not been sustainable or have failed. Ghana, like many other developing countries has put in place different interventions over the years to reforest degraded lands. These programmes have mostly been based purely on proving technical expertise. The outcomes of these interventions have not been well evaluated. The MTS is now presented as a promising land use model. But, after decades of the MTS implementation, its viability to achieve livelihood improvement or deliver livelihood security, forest resource recovery, and poverty reduction at the local arena has not been evaluated or verified. This study evaluates 15 -years of MTS implementation by local communities with the aim of reporting the system composition and growth and the products and services offered by the system, including the contribution of the system to income generation. The sustainability of the system is also assessed against gender recognition as a sustainability criterion. The results of the study will provide useful information for guiding the implementation of such rehabilitation and restoration interventions in other parts of Ghana.

\section{Methodology}

\subsection{Study Sites and Sample Size}

The study was undertaken in three (3) farming communities close to or within the PamuBerekum Forest Reserve. They are Twumkrom $\left(07^{\circ} 21^{\prime} 11^{\prime} N\right.$, $\left.2^{\circ} 48^{`} 21^{\prime \prime} \mathrm{W}\right)$, Abonsrakrom $\left(07^{\circ} 21^{`} 21^{\prime} \mathrm{N}, 2^{\circ} 48^{`} 10^{\prime \prime} \mathrm{W}\right)$ and Ntabene ( $\left.07 \mathrm{o} 26^{`} 69^{\prime \prime}, 2^{\circ} 51^{`} 17^{\prime} \mathrm{W}\right)$ all in the Dormaa District of Ghana (Figure 1) (Danquah and Zhang, 2014). The total population of these communities is about 500 and the major occupation of the people is farming of both cash and food crops. The studied communities were located within the wet semi-equatorial climate region with a double maximal rainfall regime. The mean annual rainfall is between $125 \mathrm{~cm}$ and $175 \mathrm{~cm}$. The first rainy season is from May to June; with the heaviest rainfall occurring in June while the second rainy season is from September to October. The dry seasons are quite pronounced with the main season beginning around the latter part of November and ending in February. It is usually accompanied by relative humidity of $75-80$ percent during the two rainy seasons and $70-72$ percent during the rest of the year. The highest mean temperature of the district is about $30^{\circ} \mathrm{C}$ and occurs between March and April and the lowest about $26.1^{\circ} \mathrm{C}$ in August. 


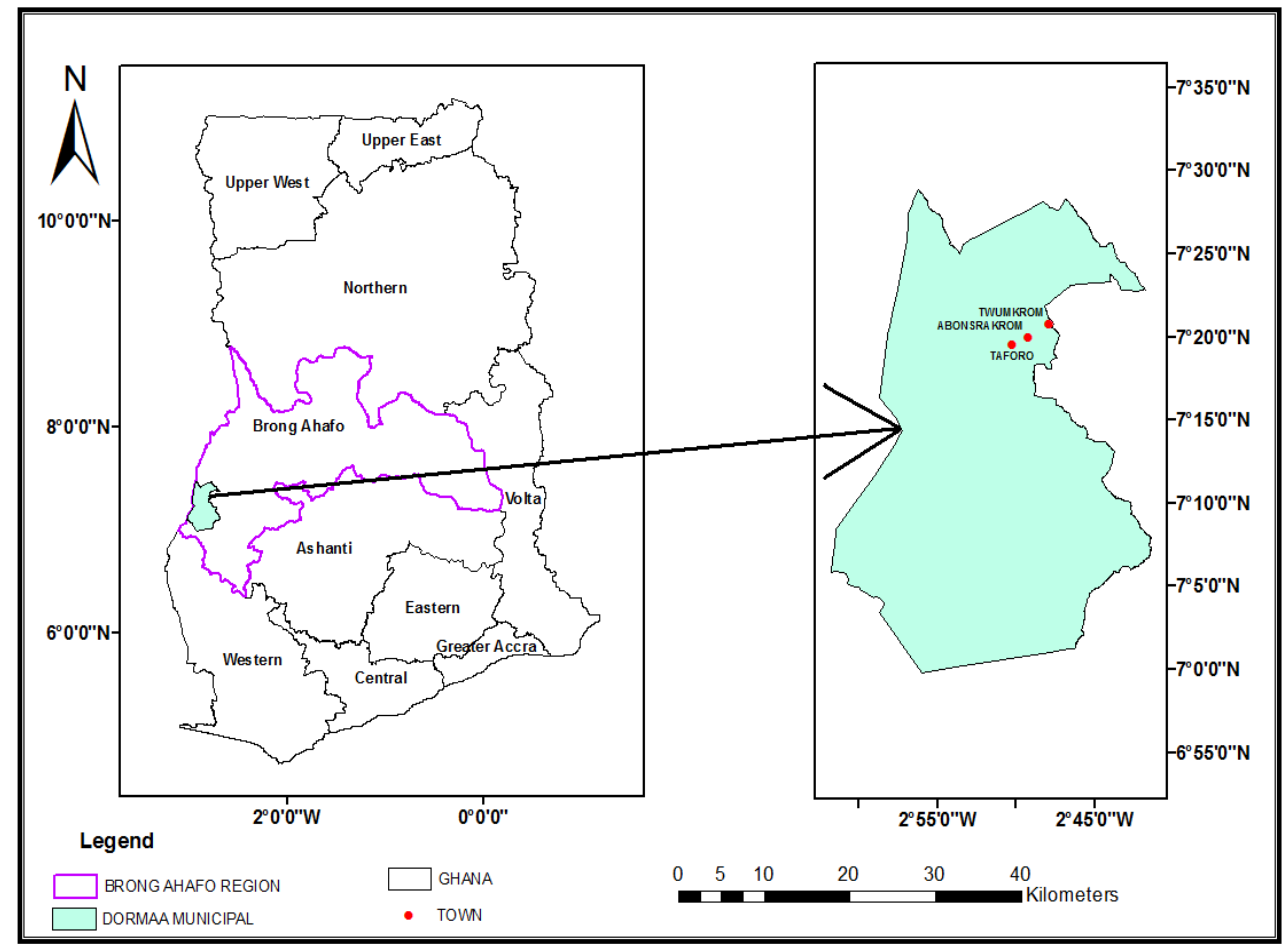

Figure 1. Map of Southern Ghana Showing Study Sites in Dormaa District in a Dry Semi-deciduous Forest Zone (Yeboah, 2016)

Selection of the farming communities for the study was purposive. Respondents were identified for interviewing during initial dialogue meetings with the major Modified Taungya System (MTS) stakeholders. Those interviewed were stakeholders who had participated in MTS. Respondents $(n=40)$ were engaged in face-to-face interviews. The interview was conducted in Twi (the Local language which the farmers speak and understand best) and responses were translated and recorded in English.

\subsection{Data Collection and Analysis}

Structured questionnaires were employed in collecting data from the farmers following procedure used by Appiah (2001), Appiah et al., 2007 and Appiah (2010). The data collected included information such as the socio-economic characteristics, incentives and benefits enjoyed, land-use agreements, responsibility sharing, motivation for sustained participation, system components, as well as growth and survival rates for the trees etc which were solicited from the 40 respondents from the three farming communities among others. The data was edited, coded, and further subjected to analysis using descriptive statistics (bar charts, percentages, means, standard error of means) through the application of the Statistical Package for Social Sciences (SPSS) version 22. 


\section{Mll Macrothink

\section{Results and Discussion}

\subsection{Demographics of MTS Participants and Gender Recognition}

Women play important roles in agriculture, undertaking a wide range of activities relating to food production, processing, and marketing; and beyond farming, they are involved in land and water management: most often they are collectors of water, firewood, and fodder. They also have access to a store of local knowledge on the medicinal use of plants and they have been in the forefront of soil conservation programmes. Women's participation in agricultural production therefore cuts across various subsectors: from planting, weeding, harvesting, and processing, as well as marketing. This necessitates their integration into planning for effective and sustainable development of agricultural practices. In view of this, the sustainability of the forest rehabilitation approach was assessed against gender recognition. This study records the high percentage of women that are involved in the MTS (Table 1). As suggested by the respondents, both men and women had equal access to agricultural lands and technical and material inputs. This suggests that the project approach provides women with opportunities in the presence of their male counterpart, which is a key principle for agricultural sustainability. Hence, this resulted positively in enhancing their farm output and income. The idea of female participation in this study relates to who takes part in the project's activities and the responsibilities involved. Thus, participation may be considered in this case as a measure of equality - both in opportunities (access to land and inputs) and outcomes (access to benefits of the system). In many instances, the participation of a good many women in project activities may not necessarily imply equality between men and women. Because in most cases women could participate in the work but may not receive the income which that work generates. Hence, equality is not always achieved where women participating in projects is high. In this study, the women respondents suggested that they receive the income and benefits associated with their labour and inputs. 
Table 1. Socio-economic information on Ghanaian farmers involved in Modified Taungya System (MTS)

\begin{tabular}{|l|l|l|l|l|l|}
\hline Variable & $\begin{array}{l}\text { Number of } \\
\text { Responses (N) }\end{array}$ & $\begin{array}{l}\text { Percentage } \\
\text { Responses (\%) }\end{array}$ & Variable & $\begin{array}{l}\text { Number of } \\
\text { Responses } \\
(\mathbf{N})\end{array}$ & $\begin{array}{l}\text { Percentage } \\
\text { Responses } \\
(\%)\end{array}$ \\
\hline Major occupation & & & Marital Status & & \\
\hline MTS Farmers & 40 & 100 & Married & 34 & 85 \\
\hline Gender & & & Divorced & 6 & 15 \\
\hline Male & 19 & 47 & Family Size & & \\
\hline Female & 21 & 53 & $1-5$ & 20 & 50 \\
\hline Age & & & $6-10$ & 18 & 45 \\
\hline $31-45 y r s$ & 12 & 30 & above 10 & 2 & 5 \\
\hline $46-60 y r s$ & 25 & 63 & $\begin{array}{l}\text { Residential } \\
\text { Status }\end{array}$ & & \\
\hline Above 60yrs & 3 & 7 & Native & 28 & 70 \\
\hline Education level & & & Migrant farmer & 12 & 30 \\
\hline Primary & 3 & 7 & $\begin{array}{l}\text { Participating } \\
\text { communities }\end{array}$ & & \\
\hline JHS & 24 & 60 & $\begin{array}{l}\text { Abonsrakrom } \\
\text { Twumkrom }\end{array}$ & $\begin{array}{l}20 \\
6\end{array}$ \\
\hline None & 13 & 33 & Ntabene & 14 & 50 \\
\hline
\end{tabular}

\subsection{The Structural Component of the Modified Taungya System (MTS)}

Agricultural systems consist of components that are united by interaction and interdependence, and these components are managed to achieve specific agricultural objective (McConnell and Dillon, 1997). Based on the responses from respondents, the MTSs being practiced are agrisilviculture in nature. In this system, agricultural crops are intercropped with tree crops within the interspace between the trees. Under this system agricultural crops can be grown under rain-fed condition for up to 3 years. The data collected reveals that all the farmers planted a mixture of tree species (Terminalia superba, Khaya ivorensis, Terminalia ivorensis, Nauclea diderrichii, Ceiba pentandra, Entandophragma cylindricum, Antiaris toxicaria, Afzelia africana) with a mixture of vegetables and other food crops: mainly cocoyam (Xanthosoma sagittifolium), plantain(Musa paradisiaca), vegetables, maize (Zea mays) and yam (Dioscorea spp.). The most planted tree was Terminalia superba (Ofram) which represented $18 \%$ of the tree species that were planted followed by Khaya ivorensis (mahogany), Terminalia ivorensis (Emire) and Nauclea diderrichii (Kusia) which represented $17 \%$ each of the trees species planted. Ceiba pentandra, and Entandophragma cylindricum represented $15 \%$ and $10 \%$ of trees planted respectively. The least planted species were Antiaris toxicaria (Kyenkyen) and Afzelia Africana (Papao) which represented 3\% each (Figure 2).

A wider spacing than normal, of 4 meters between trees, was adopted to ensure the tree population allowed for the interplanting of the crops and easy cultural operation. As expected, farmers indicated that the systems were deliberately selected so that they could get multiple 
outputs from the use of multiple indigenous trees. It is structurally and functionally more complex than monoculture.

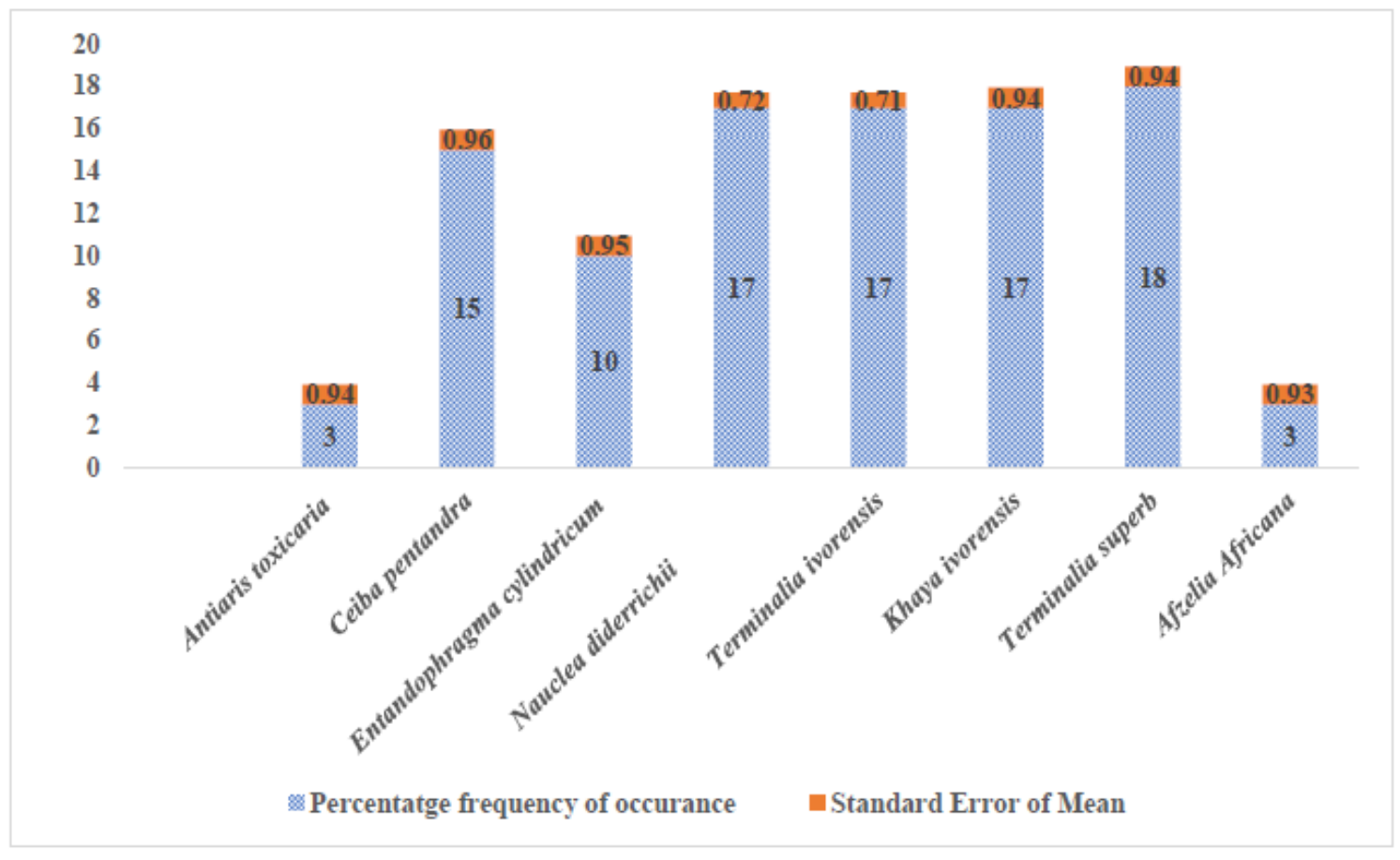

Figure 2. Farmers' preferences for trees species for Modified Taungya Systems in Ghana

\subsection{Performance of the Tree Crops in Modified Taungya System (MTS)}

The overall percentage survival rate per hectare of MTS was about $71 \%$ (Table 2). Average height and diameter at breast height of trees after 15 years of growth were $22 \mathrm{~m}$ and $23 \mathrm{~cm}$ respectively (Table 2 and Table 3). The recorded sapling mortality and growth rates in this study did not significantly differ from what is recorded by other studies for similar systems. In terms of species, mortality and growth rates have been previously shown to differ significantly between tree species. For instance, Appiah (2011) reported similar survival and growth rates for some of the tested tree species including $C$. pentandra, and $T$. ivorensis. Mortality in the MTS could be related to several factors, such as the size of seedling at the time of planting, and cultural practices adopted by each farmer. Other possible explanation for the recorded mortality rate could be that farmers deliberately kill trees on farms to prevent canopy closure and allow continues use of the MTS land for cropping. This is supported by the studies (e.g. Agyemang et al., 2003a; Acheampong and Marfo, 2011; Acheampong et al., 2016) conducted on the death rate of trees in MTS. Considering all these factors, attributing the survival rates of the trees to the species or management practices of the famers or any particular factor may not be a straightforward task. Nonetheless, the results do show that the rate of tree retention on farms is good. The results of this study suggest that active community involvement in tree planting and maintenance may improve tree survival (Appiah 2001; Blay et al., 2007, Appiah et al., 2015). Tree survival under the MTS is of particular interest to the Forestry Commission because tree survival relates to productivity and success 


\section{Macrothink}

Environmental Management and Sustainable Development

ISSN 2164-7682

2020, Vol. 9, No. 3

of the restoration practices of the Commission. Furthermore, managing the rehabilitated forests effectively is predicated on accurate information pertaining to such characteristics of trees as the height and diameter growth (Hogland et al., 2020)

\subsection{Functional Basis of the Modified Taungya System (MTS)}

\subsubsection{The Productive Functions}

In addition to food which farmers unanimously said is part of the productive function of the MTS, they have also recorded increases in income over the years (Table 4). Farmers have reported about $17 \%$ to $49 \%$ increases in income from engaging in MTS primarily due to restored availability of bush meat, fodder, fuel wood, and medicine etc. which were marketable products (Table 5).

Table 2. Performance of the tree species established using Modified Taungya Systems covering a total area of 40 hectares

\begin{tabular}{|l|l|l|l|l|}
\hline Dependent Variable & \multirow{2}{*}{ Mean } & Std. Error & 95\% Confidence Interval \\
\cline { 5 - 6 } & & & Lower Bound & Upper Bound \\
\hline Number planted per hectare in 2005 & & & & \\
\hline & 625 & - & 625 & 625 \\
\hline Number of trees counted per hectare in 2016 & 441 & 2.3 & 439 & 442 \\
\hline & & & & \\
\hline Mortality per hectare over 15 years & 184 & 0.95 & 183 & 185 \\
\hline & & & & \\
\hline Average total height of trees (m) in 2016 & 22 & 2.4 & 13 & 30 \\
\hline & & & & 35 \\
\hline Diameter at breast height of trees (cm) in 2016 & 23 & 2.2 & 10 & 3 \\
\hline
\end{tabular}

Table 3. Mean number of number of trees per hectare of MTS grouped according to diameter classes

\begin{tabular}{|l|l|l|l|l|l|l|l|l|l|l|l|}
\hline Tree species & \multicolumn{8}{|l|}{ Diameter at breast height classes $(\mathbf{c m}$ 15 years after planting } & Total \\
\hline & $\mathbf{5 - 1 0}$ & $\mathbf{1 1 - 2 0}$ & $\mathbf{2 1 - 5 0}$ & $\mathbf{5 1 - 7 0}$ & $\mathbf{7 1 - 9 0}$ & $\mathbf{9 1 - 1 1 0}$ & $\mathbf{1 1 1 - 1 3 0}$ & $>=\mathbf{1 3 0}$ & \\
\hline Afzelia Africana & 3 & 8 & 2 & 0 & 0 & 0 & 0 & 0 & 13 \\
\hline Terminalia superba & 0 & 8 & 72 & 0 & 0 & 0 & 0 & 0 & 80 \\
\hline Terminalia ivorensis & 0 & 6 & 69 & 0 & 0 & 0 & 0 & 0 & 75 \\
\hline Antiaris toxicaria & 2 & 10 & 1 & 0 & 0 & 0 & 0 & 0 & 13 \\
\hline Nauclea diderrichii & 2 & 25 & 48 & 0 & 0 & 0 & 0 & 0 & 75 \\
\hline Entandophragma cylindricum. & 0 & 4 & 40 & 0 & 0 & 0 & 0 & 0 & 44 \\
\hline Ceiba pentandra & 0 & 6 & 60 & 0 & 0 & 0 & 0 & 0 & 66 \\
\hline Khaya ivorensis & 1 & 9 & 65 & & 0 & 0 & 0 & 0 & 75 \\
\hline Total & 8 & 76 & 357 & 0 & 0 & 0 & 0 & 0 & 441 \\
\hline
\end{tabular}

Given that rural women in Ghana participate largely in agricultural activities as a main source of food and income, it is worth noting the potential of MTS as a lucrative practice for improving the livelihood of local people particularly local women. The data shows that these interventions through MTS have improved the income status of $53 \%$ of the women in the 
studied communities.

Table 4. Annual Income changes from Modified Taungya System (MTS) only as reported by farmers $(n=40)$

\begin{tabular}{|l|l|l|}
\hline Income (USD) group & $\begin{array}{l}\text { Before MTS Number of } \\
\text { farmers per income group }\end{array}$ & $\begin{array}{l}\text { After MTS Percentage increase in } \\
\text { income over 15 years period }\end{array}$ \\
\hline 51 and below & 5 & $29 \%$ \\
\hline $52-104$ & 9 & $37 \%$ \\
\hline $104-156$ & 12 & $49 \%$ \\
\hline 156 and above & 14 & $17 \%$ \\
\hline
\end{tabular}

Table 5. Respondents rating their access to services/products while practicing MTS

\begin{tabular}{|l|l|l|l|}
\hline Service & Respondent (\%) & Now/Currently (Use scale 1) & 15years ago (Use scale 1) \\
\hline Bush meat & 80 & 1 & 3 \\
& 20 & 2 & 4 \\
\hline Timber & 70 & 4 & 4 \\
& 30 & 3 & 3 \\
\hline Fuelwood & 100 & 1 & 3 \\
\hline Medicine & 65 & 1 & 3 \\
& 35 & 2 & 3 \\
\hline Others: fruits, seeds, etc. & 50 & 2 & 4 \\
& 50 & 2 & 3 \\
\hline
\end{tabular}

Scale: $1=$ High supply $\quad 2=$ Moderate supply/activity $\quad 3=$ Poor supply $\quad 4=$ No supply

\subsubsection{Protective functions of the MTS}

Farmers agree that MTS is an improved system that enhances soil conservation and controls erosion (Table 6). As explained by farmers, the systems contribute to more efficient recycling of nutrients by deep rooted trees on the site. It also helps to improve soil moisture and increases soil nutrient through a combination of mulching and shading, and through addition and decomposition of litterfall. Erosion control is explained from the point of view that the system helps to reduce surface run-off, nutrient leaching and soil erosion through impeding effect of tree roots and stems on these processes. The observations by farmers regarding the soil conservation values of the MTS systems are supported by several studies on land restoration that suggest that reforesting of lands through plantations can reduce erosion or reclaim degraded landscapes (e.g. Woś et al., 2020). Such tree dominated systems have been important intervention options especially for facilitating the recovery of biodiversity and native forest species and for the rehabilitation of degraded forest lands (Garrity, 2004; Makundi and Sathaye, 2004). In addition to restoring forest goods (e.g., fuel wood, construction material, medicine) and services and other ecological functions of the agricultural landscape, the farmers suggested that an increase in tree numbers on farms will allows their land use practice to act as carbon sinks which can help to reduce atmospheric 
$\mathrm{CO}_{2}$ concentration by sequestrating greenhouse gases (Soto-Pinto et al. 2010). They indicated that the trees also ensure the provision of a shaded environment needed for the cultivation of their agricultural crops. Studies have reported the role of tree-dominated systems such as the MTS in environmental services (including air quality control), biodiversity recovery and pest control within agricultural landscapes (see, Table 7). References can be made to studies in Ghana (e.g. Appiah 2011); Congo (e.g. Bernhard-Reversat, 2001), and Uganda (e.g. Fimbel and Fimbel, 1996).

Table 6. Farmers perceptions of protective services provided by the MTS

\begin{tabular}{|l|c|l|l|l|}
\hline Service Type & \multicolumn{2}{|l|}{$\begin{array}{l}\text { Land use } \\
\text { under MTS }\end{array}$} & \multicolumn{2}{|l|}{$\begin{array}{l}\text { Land use prior to } \\
\text { Establishment } \\
\text { MTS }\end{array}$} \\
\hline & Scale & $\begin{array}{l}\text { Respondents } \\
\text { of }\end{array}$ & Scale & $\begin{array}{l}\text { Respondents } \\
(\%)\end{array}$ \\
\hline The land use supports soil conservation \& erosion control & 1 & 80 & 3 & 20 \\
\hline The land use supports climate regulation/carbon sink & 1 & 75 & 3 & 25 \\
\hline The land use prevents pest and diseases infections & 2 & 85 & 3 & 15 \\
\hline The land use improves air quality & 1 & 90 & 3 & 10 \\
\hline Other: The land use helps to reduce pressure on natural forests & 2 & 88 & 2 & 12 \\
\hline
\end{tabular}

Scale: $1=$ Agree completely $\quad 2=$ Moderately agree $\quad 3=$ Disagree

Table 7. Economic and ecological useful plants in MTS. Their conservation status at a local level (Star Rating) and on global scale (IUCN Red-List)

\begin{tabular}{|c|c|c|c|c|c|}
\hline \multirow{2}{*}{$\begin{array}{l}{ }^{\#} \text { Timber } \\
\text { Species }\end{array}$} & \multicolumn{3}{|c|}{ Usefulness to respondents } & \multirow[b]{2}{*}{$\begin{array}{l}* \text { Conservation } \\
\text { Status (Star } \\
\text { Rating) }\end{array}$} & \multirow[b]{2}{*}{$\begin{array}{l}{ }^{\dagger} \text { IUCN } \\
\text { Red-List } \\
\text { Rating }\end{array}$} \\
\hline & Family & ${ }^{\mathrm{EC}}$ Economic value & Ecological & & \\
\hline $\begin{array}{l}\text { Terminalia superba } \\
\text { (Pioneer species) }\end{array}$ & Combretaceae & $\begin{array}{l}\text { Bark, leaves and roots are used for medicine } \\
\text { Dead branches used as fuel wood; wood is } \\
\text { valued for interior joinery, door posts and } \\
\text { panels, furniture, office-fittings, crates, } \\
\text { matches. It is used locally for temporary house } \\
\text { construction, planks, roof shingles, canoes, } \\
\text { paddles, coffins, boxes and domestic utensils }\end{array}$ & $\begin{array}{l}\text { Shade tree } \\
\text { Soil } \\
\text { conservation }\end{array}$ & Pink & DD \\
\hline Khaya ivorensis & Meliaceae & $\begin{array}{l}\text { It attracts high premium on both local and } \\
\text { foreign timber market; the bark has medicinal } \\
\text { properties and it is used in manufacturing } \\
\text { alcoholic beverages called 'bitters'. }\end{array}$ & $\begin{array}{l}\text { Soil } \\
\text { conservation }\end{array}$ & Scarlet & $\mathbf{V U}$ \\
\hline $\begin{array}{l}\text { Terminalia } \\
\text { ivorensis } \\
\text { (Pioneer species) }\end{array}$ & Combretaceae & $\begin{array}{l}\text { Bark used for medicine, timber, wood is valued } \\
\text { for interior joinery, door posts and panels, } \\
\text { furniture, office-fittings, crates, matches, and } \\
\text { particularly for veneer and plywood. It is used }\end{array}$ & $\begin{array}{l}\text { Shade tree } \\
\text { Soil } \\
\text { conservation }\end{array}$ & Red & $\mathbf{V U}$ \\
\hline
\end{tabular}




\begin{tabular}{|c|c|c|c|c|c|}
\hline & & $\begin{array}{l}\text { locally for temporary house construction, } \\
\text { planks, roof shingles, canoes, paddles, coffins, } \\
\text { boxes and domestic utensils }\end{array}$ & & & \\
\hline $\begin{array}{l}\text { Nauclea diderrichii } \\
\text { (Pioneer species) }\end{array}$ & Rubiaceae & $\begin{array}{l}\text { Used in joinery, flooring and marine } \\
\text { construction; railway sleeper: locally use as } \\
\text { medicine, condiment in palm nut soup and fuel } \\
\text { wood; effective in restoring native woodland, } \\
\text { rapid growth makes it more suitable for } \\
\text { agroforestry systems }\end{array}$ & $\begin{array}{l}\text { Shade tree } \\
\text { Soil } \\
\text { conservation }\end{array}$ & Scarlet & $\mathbf{V U}$ \\
\hline $\begin{array}{l}\text { Ceiba pentandra } \\
\text { (Pioneer species) }\end{array}$ & Bombaceae & $\begin{array}{l}\text { Silk cotton tree as is called locally. The } \\
\text { cotton is used to fill pillows and mattress. } \\
\text { Dead wood provides medium for culture of } \\
\text { some species of mushrooms highly relish by } \\
\text { communities; building construction and } \\
\text { veneer (plywood). Suitable for soil erosion } \\
\text { control and watershed protection. }\end{array}$ & $\begin{array}{l}\text { Soil } \\
\text { conservation } \\
\text { Shade }\end{array}$ & & LC \\
\hline $\begin{array}{l}\text { Entandophragma } \\
\text { cylindricum } \\
\text { (Non-pioneer } \\
\text { Light Demanding) }\end{array}$ & Meliaceae & $\begin{array}{l}\text { The bark is used in traditional medicine, as a } \\
\text { shade plant in cocoa agroforestry systems, } \\
\text { the bark as dye in traditional textile industry, } \\
\text { veneer, exterior and interior joinery, } \\
\text { furniture, flooring }\end{array}$ & Shade tree & Scarlet & $\mathbf{V U}$ \\
\hline $\begin{array}{l}\text { Antiaris toxicaria } \\
\text { (Pioneer species) }\end{array}$ & Moraceae & $\begin{array}{l}\text { The bark has high concentrations of tannins } \\
\text { which serve as dyes in traditional textile } \\
\text { industry, seeds are edible, used in folk } \\
\text { medicine, veneer, effective in soil } \\
\text { amelioration, timber }\end{array}$ & $\begin{array}{c}\text { Soil } \\
\text { conservation }\end{array}$ & Red & LC \\
\hline $\begin{array}{l}\text { Afzelia Africana } \\
\text { (Non-pioneer } \\
\text { Light Demanding) }\end{array}$ & Fabaceae & $\begin{array}{l}\text { Use in indigenous religion and medicine, } \\
\text { fruits are edible; excellent timber substitute } \\
\text { for mahoganies, leaves rich in nitrogen and } \\
\text { effective in soil amelioration }\end{array}$ & $\begin{array}{l}\text { Soil } \\
\text { conservation } \\
\text { (Nitrogen } \\
\text { fixation) }\end{array}$ & Red & $\mathbf{V U}$ \\
\hline
\end{tabular}

Notes:

\#As at the time of study, there was no timber harvesting. Pioneer species $(\mathrm{P})$ are those that germinate and grow in open spaces and play a vital role by beginning the cycling of nutrients by mining and accumulating available nutrients. P species also create favorable conditions for germination of primary forest species that need shade to germinate and grow. Non-Pioneer Light Demanding (NPLD) are species that germinate in shade conditions but need gaps in the canopy to develop further. *Star rating (Source: Hawthorne and Abu-Juam, 1995). These star ratings allow for the calculation of the Genetic Heat Index (GHI) of an area to determine its conservation status (Hawthorne and Abu-Juam, 1995). The Genetic Heat Index reflects the concentration of rare plant species in an area and allows for prioritization of areas for conservation purposes (FAO, 2012).

*Black Star species: Urgent attention to conservation of populations needed. Rare internationally and at least uncommon in Ghana. Ghana must take particular care of these species.

*Pink Star species: Common and moderately exploited. This group has a sub group called promotable, Pinks 
where Government is encouraging their exploitation to reduce their numbers.

*Gold star species: Fairly rare internationally and/or locally. Ghana has some inescapable responsibility for maintaining these species

*Blue Star species: Widespread internationally but rare in Ghana or vice versa Scarlet Common but under serious pressure from heavy exploitation. Exploitation is now restricted

*Red Star species: Common, but under pressure from exploitation.

*Green Star species: No particular conservation concern: Others Non forest species or excluded from analysis for other reasons.

*Scarlet Star: Common, but under serious pressure from heavy exploitation; is highly restricted.

${ }^{\dagger}$ Conservation status: This is a measure of likelihood of that species continuing to survive either in the present day or the future and the potential threat to their survival. It is an assessment that monitors population dynamics of species over period of time, taking into consideration other environmental factors. IUCN Conservation Red List of Threatened Species is a global conservation status listing and ranking of species (fauna and flora). It is basically a checklist of taxa that have undergone an extinction risk assessment using the IUCN Red List Categories and Criteria (Vulnerable; Endangered; Critically Endangered; Extinct, Extinct in the Wild, Near Threatened, Least Concern, Data deficient and Not Evaluated). Source: (International Union conservation of Nature (IUCN) 2020; ScienceDaily 2020; Danquah et al. 2019)

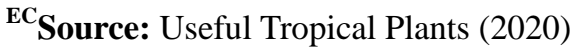

Key: VU =Vulnerable; $\mathbf{E N}=$ Endangered; $\mathbf{C R}=$ Critically Endangered; $\mathbf{L C}=$ Least Concern; $\mathbf{D D}=$ Data deficient

\subsection{Conservation Status of Tree Species Being Planted by Farmers}

Scarlet or Red Star species, commonly referred to as timber species in Ghana, dominate the species being planted by farmers in the area with 7 species and a total frequency of about 361 stems per ha. followed by Pink Star (common and moderately exploited as timber) (five species) with a frequency of about 80 stems per ha (Table 7). According to the star ratings, no Black Star species (highly significant in the context of global biodiversity) were planted by farmers. The results show that species, for example Hildegardia barteri, which is among those that are considered rare and their survival in Ghana is of concern, and Talbotiella gentii, a Black Star species found only in Ghana and has been completely depleted (GoG, 2002), are not part of the promoted plantation species, although attention to its conservation has been raised (Appiah, 2011). These findings suggest that some critical species of the landscape may be lost if efforts are not made to promote the planting of such species that are rare internationally as well as being listed on the IUCN Red List as Critically Endangered (IUCN, 2019)

\section{Concluding Remarks}

It is clear from the results that, female participation in the project activities is significant and may have contributed to the reported outcome because women have for decades been important players in the development of subsistence farming in developing countries. Evidently, the non-timber forest products, (e.g. fuelwood, medicine) made available from practising MTS appear to have had a significant impact on the community livelihood with significant changes in annual income. The farms clearly have many trees surviving that have 
economic, social, and ecological significance. This is reflective of the potential for increased income to farmers when the trees are ready to be harvested as timber. Subsequently, farmers' livelihood and quality of life will improve further when the trees are harvested and sold. Considering the results highlighted in the restoration approach, MTS indeed has the potential to support biodiversity recovery within degraded forest reserves in Ghana as well as to improve the livelihoods of farmers.

\section{Acknowledgement}

The study was conducted within the International Tropical Timber Organisation (ITTO)-Forestry Research institute of Ghana Project on Rehabilitation of degraded forests with collaboration of local communities Ghana-ITTO Project (PD 30/97 Rev 6 (F). Mr Yeboah Badu, who is a co-author of this articles is acknowledged for collecting the field data of which part was used for his Master thesis. Thanks to Murray Fagg for his comments and suggestions on the paper.

\section{References}

Acheampong, E., Insaidoo, T. F. G., \& Ros-Tonen, M. A. F. (2016). Management of Ghana's modified taungya system: challenges and strategies for improvement. Agroforest Systems, 90, 659-674. https://doi.org/10.1007/s10457-016-9946-7

Acheampong, E., \& Marfo, E. (2011). The impact of tree tenure and access on chainsaw milling in Ghana. Ghana Journal of Forestry, 27, 68-86.

Appiah, M. (2001). Co-Partnership in Forest Management: The Gwira-Banso Joint Forest Management Project in Ghana. Environment, Development and Sustainability, 3, 343-360. https://doi.org/10.1023/A:1020879510134

Appiah, M. (2011). Changes in species composition in a deciduous agroecosystem in Ghana following plantation establishment. Agroforestry Systems, 82, 57-74.

https://doi.org/10.1007/s10457-011-9459-3

Appiah, M., Fagg M., \& Pappinen A. (2015). A Review of Reforestation Approaches in Ghana: Sustainability and Genuine Local Participation Lessons for Implementing REDD+ Activities. European Journal of Scientific Research, 131(1), 70-99.

Appiah, M., Damnyag, L., Blay, D., \& Pappinen, A. (2010). Forest and agroecosystem fire management in Ghana. Mitigation and Adaptation of Strategies for Global Change, 15(6), 551-570. https://doi.org/10.1007/s11027-010-9236-z

Agyeman, V. K., Kasanga, K. R., Danso, E., Marfo, K. A., Whiteman, A., Asare, A. B., Yeboah, O. M., \& Agyeman, F. (2003a). Equitable Forest Reserve Plantation Revenue Sharing in Ghana. Report for FAO.

Agyeman, V. K., Kasanga, K. R., Danso, E., Marfo, K. A., Whiteman, A., Asare, A. B., Yeboah, O. M., \& Agyeman, F. (2003b). Revising the taungya plantation system: new revenue-sharing proposal from Ghana. Unasylva, 212(54), 40-43. 
Bauhus, J., van der Meer, P. J., \& Kanninen, M. (2010). Ecosystem goods and services from plantation forests. Earthscan Ltd, Dunstan House, London, UK. pp. 277.

https://doi.org/10.4324/9781849776417

Blanford, H. R. (1958). Highlights of 100 years of forestry in Burma. Empire Forestry Review, $37(1), 33-42$.

Blay, D., Appiah, M., Damnyag, L., Dwomoh, F., Pappinen, A., \& Luukkanen, O. (2007). Involving local farmers in rehabilitation of degraded tropical forests: some lessons from Ghana". Environment, Development and Sustainability, 10, 503-518.

https://doi.org/10.1007/s10668-006-9077-9

Blakesley, D., Elliott, S., Kuarak, C., Navakitbumrung, P., Zangkum, S., \& Anusarnsunthorn, V. (2002). Propagating framework tree species to restore seasonally dry tropical forest: implications of seasonal seed dispersal and dormancy. Forest Ecology and Management, 164, 31-38. https://doi.org/10.1016/S0378-1127(01)00609-0

Bernhard-Reversat F (Ed). (2001). Effect of exotic tree plantations on plant diversity and biological soil fertility in the Congo savanna: with special reference to Eucalyptus. CIFOR, Bogo. pp. 71.

Carpenter, F. L., Nichols, J. D., \& Sandi, E. (2004). Early growth of native and exotic trees planted on degraded tropical pasture. Forest Ecology and Management, 196, 367-378. https://doi.org/10.1016/j.foreco.2004.03.030

Danquah, J. A., Appiah, M., Osman, A., \& Pappinen, A. (2019). Geographic distribution of global economic important mahogany complex: A review. Annual Research \& Review in Biology, 34(3), 1-22. https://doi.org/10.9734/arrb/2019/v34i330154

Danquah, J. A. (2015). Analysis factors influencing farmers' voluntary participation in reforestation programme in Ghana. Forest, Trees and Livelihood. participation in reforestation program in Ghana. Forests, Trees and Livelihoods, 24(3), 176-189.

https://doi.org/10.1080/14728028.2015.1025862

Danquah, J. A., \& Zhang, C. (2014). Tree species diversity in a post-bushfire disturbed dry semi-deciduous forest: Implication to restoration ecology. International Journal of Advanced Biological Research, 4(3), 271-279.

Danquah, J. A. (2012). Restoration of degraded dry semi semideciduous forest ecosystems in Ghana: Effects of African mahogany species on soil chemistry, tree diversity and the application of leaf morphometrics for provisional seed zonation. Dissertationes Forestales. pp. 148. https://doi.org/10.14214/df.148

Danquah, J. A., Sarpong, D. B., \& Pappinen, A. (2012). Causal relationship between African mahoganies exports and deforestation in Ghana: Policy implications. Environment, Development and Sustainability, 15, 51-66. https://doi.org/10.1007/s10668-012-9373-5

McConnell, D. J., \& Dillon, J. L. (1997). Farm Management for Asia: a Systems Approach. (FAO Farm Systems Management Series - 13) FAO, Rome. 


\section{Ml Macrothink}

Environmental Management and Sustainable Development

ISSN 2164-7682

2020, Vol. 9, No. 3

Eshaghi, R. J., Manthey, M., \& Mataji, A. (2009). Comparison of plant species diversity with different plant community in deciduous forests. Int J Environ Sci Technol, 6(3), 389-394. https://doi.org/10.1007/BF03326077

Fimbel, R. A., \& Fimbel, C. C. (1996). The role of exotic conifer plantations in rehabilitating degraded tropical forest lands: a case study from the Kibale Forests in Uganda. Forest Ecology Management, 81, 215-226, https://doi.org/10.1016/0378-1127(95)03637-7

FAO (2012). The State of the World's Forest Genetic Resources Country Report: GHANA Ministry of Lands and Natural Resources APRIL 2012.

Garrity, D. P. (2004) Agroforestry and the achievement of the millennium development goals. Agroforestry Systems, 61, 5-17. https://doi.org/10.1007/978-94-017-2424-1_1

GoG, (2002). National Biodiversity Strategy for Ghana. Ministry of Environment and Science, Ghana, p. 53.

Hawthorne, W. D., \& Abu-Juam, M., (1995). Forest Protection in Ghana (With Particular Reference to Vegetation and Plant Species). IUCN Gland, Switzerland and Cambridge, UK.

Hogland, J., Affleck, D. L., Anderson, N., Seielstad, C., Dobrowski, S., Graham, J., Smith, R. (2020). Estimating Forest Characteristics for Longleaf Pine Restoration Using Normalized Remotely Sensed Imagery in Florida USA. Forests, 11, 426.

https://doi.org/10.3390/f11040426

International Union conservation of Nature (IUCN), (2019). The IUCN Red List of Threatened Species. Version 2019-3. [Online] Available: https://www.iucnredlist.org/

Jonsson, R. (2009). Forest Products Markets. External drivers affecting Swedish forests and forestry. Future Forests Working Report. SLU Alnarp.

Makundi, W. R., \& Sathaye, J. A. (2004). GHG mitigation potential and cost in tropical forestry-relative role for agroforestry. Environment, Development and Sustainability, 6(1/2), 235-260. https://doi.org/10.1023/B:ENVI.0000003639.47214.8c

Mansourian, S., Vallauri, D., \& Dudley, N. (2005). Overview of technical approaches to restoring tree cover at the site level forest restoration in landscapes. Springer, New York, pp 241-249. https://doi.org/10.1007/0-387-29112-1_35

McConnell, D. J., \& Dillon, J. L. (1997). Farm Management for Asia: a Systems Approach. (FAO Farm Systems Management Series - 13) FAO, Rome.

Montagnon, F. (2000). Accumulation in above-ground biomass and soil storage of mineral nutrients in pure and mixed plantations in a humid tropical lowland. Forest Ecology and Management, 134, 257-270. https://doi.org/10.1016/S0378-1127(99)00262-5

Pugha, T. A. M., Lindeskog, M., Smith, B., Poulter, B., Arneth, A., Haverd, V., \& Calle, L. (2019). Role of forest regrowth in global carbon sink dynamics. PNAS, 116(10), 4382-4387. https://doi.org/10.1073/pnas.1810512116 


\section{Macrothink}

Remeš, J., Pulkrab, K., Bílek, L., Podrázský, V. (2020). Economic and Production Effect of Tree Species Change as a Result of Adaptation to Climate Change. Forests, 11, 431.

https://doi.org/10.3390/f11040431

Ribot, J. C., \& Larson, A. M. (2005). Democratic Decentralization through a Natural Resource Lens: An Introduction. Routledge Taylor and Francis Group. pp. 1-4

Ribot, J. C., \& Oyono, P. R. (2006). Introduction: Decentralization and Livelihoods in Africa. Africa Development, 31(2), 1.

Science Daily. (2020). Conservation status. [Online] Available: https://www.sciencedaily.Com/terms/conservation_status.htm

Soto-Pinto, L., Anzueto, M., Mendoza, J., Jimenez-Ferrer, G., \& de Jong, B. (2010). Carbon sequestration through agroforestry in indigenous communities of Chiapas, Mexico. Agroforestry Systems, 78(1), 39-51. https://doi.org/10.1007/s10457-009-9247-5

UPStree. (2017). Agriculture-Agroforestry-Comprehensive Coverage. [Online] Available: https://upsctree.com/2017/07/15/agriculture-agroforestry-comprehensive-coverage/

Useful Tropical Plants (2020). Useful Tropical Plants Database. [Online] Available: http://tropical.theferns.info/

Woś, B., Józefowska, A., Pająk, M., Chodak, M., Frouz, J., \& Pietrzykowski, M. (2020). Carbon and Macronutrient Budgets in an Alder Plantation Grown on a Reclaimed Combustion Waste Landfill. Forests, 11, 430. https://doi.org/10.3390/f11040430

Yeboah, B. (2016). Sustainability Assessment of the Modified Taungya System in Dormaa District of Ghana: 15- Years after Implementation. University of Eastern Finland, Faculty of Science and Forestry and CSIR-FORIG/UEF Graduate School, Master's thesis in Bio-Economy and Natural Resources Management (ECORES). p. 55.

\section{Copyright Disclaimer}

Copyright for this article is retained by the author(s), with first publication rights granted to the journal.

This is an open-access article distributed under the terms and conditions of the Creative Commons Attribution license (http://creativecommons.org/licenses/by/4.0/). 